\title{
A Research Study on Estimation of Stature from Middle Finger Length in Uttar Pradesh State
}

\author{
Deepa Durga Roy ${ }^{1}$ \\ ${ }^{1}$ Assistant Professor, Department of Forensic Medicine and Toxicology, Heritage Institute of Medical Sciences, \\ Varanasi, Uttar Pradesh, India.
}

\section{ABSTRACT}

\section{BACKGROUND}

Middle finger as a parameter for stature estimation has been studied extensively over the years. It has also been concluded that there is indeed a positive correlation between height and middle finger length. However, it has been stressed upon in published literature, that there is a need for population and region-specific studies for further deriving an accurate formula. Keeping this in mind, the current study was undertaken, to evaluate the relationship between stature and middle finger length in Uttar Pradesh region.

\section{METHODS}

A descriptive study of a total of 90 subjects, between ages of 18 and 25 years was studied in the Department of Forensic Medicine and Toxicology, HIMS, Varanasi, of which 45 were male and 45 were female. The middle finger length of both hands was measured from proximal flexion crease to the tip of middle finger, using digital vernier calliper. Data thus collected was analysed using SPSS software and a linear regression formula was calculated. The sample size estimation was done at convenience.

\section{RESULTS}

The middle finger length showed a highly significant correlation with height. However, it was observed that the right middle finger length $(r=0.760)$ shows greater correlation with stature than left middle finger length $(r=0.701)$.

\section{CONCLUSIONS}

The present study goes on to prove that the middle finger length can be used as a successful predictor of height of an individual with the right middle finger length being a better determinant of stature than left middle finger length in the region of Uttar Pradesh.

\section{KEY WORDS}

Middle Finger Length, Height, Stature Estimation
Corresponding Author: Dr. Deepa Durga Roy, Department of Forensic Medicine \& Toxicology, Heritage Institute of Medical Sciences, NH-2, Bhadwar, Varanasi, Uttar Pradesh, India.

E-mail: deepadurgaroy@gmail.com

DOI: $10.14260 / j e m d s / 2019 / 646$

Financial or Other Competing Interests: None.

How to Cite This Article: Roy DD. A research study on estimation of stature from middle finger length in Uttar Pradesh state. J. Evolution Med. Dent. Sci. 2019;8(39):2972-2975, DOI: 


\section{BACKGROUND}

In today's world where man made mass disasters are rampant be it terrorist bombing, wars, aeroplane crashing or trains derailing, need for identification of the unknown and unidentified has become more common and more urgent. Catastrophes require a collective team effort and collaboration between experts is a must for identification of corpses. Forensic pathologist and odontologist play a major part in this. Identification can be anatomical based or mathematical based. While anatomical identification is more popular, mathematical based identification have proven to be useful and precise adjuncts to investigation. Preliminary identification of an individual is done from parameters like race, age, sex, stature. These form the cornerstones of descriptive data in identification. Thus, stature forms a key element in identification of individual especially in dismembered or decomposed bodies, amputated and fragmented remains. Stature has a positive correlation with several parts of the human body.1-5

Superimposition and photograph or videograph technique has been previously employed, for identification, when only the skull was available on autopsy. Numerous studies have been conducted using various cephalo-facial measurements to determine stature of an individual, thus proving that even skull alone can be useful in identification and stature estimation. ${ }^{6-8}$ The necessity of availability of a complete bone for identification has also been eliminated in certain studies, which have successfully predicted stature using fragments of long bones. ${ }^{9}$ Dimensions of cervical, thoracic, lumbar, thoraco-lumbar (T-L) and cervico-thoracolumbar (C-T-L) segments of the spine have been used to determine height in badly mutilated and severely burnt bodies. $^{10}$ It is well established that long bones are the absolute favourite of an anthropologist for stature calculation. ${ }^{11,12}$ Amongst the long bones, femur continues to be the reigning champion. Researchers have repeatedly established a positive correlation between length of the body and greatest length of femur. ${ }^{13,14}$ It is an established fact that a formula derived for stature determination in one population is not reliably applicable to another population. There is common miscalculation of height in the very tall or short individuals of the population. Hence, a research was conducted to obtain a regression formula for people of different stature categories (Short, medium, and tall). ${ }^{15}$ Race, ethnicity and nutrition, all have a bearing on stature estimation when calculated from different body parts. This is an important reason for conducting the same research in different parts of the world and in different regions within the same country.16,17,18 A simple yet effective method of personal identification is using foot measurements. Foot length, breadth and foot circumference, have been used to derive population specific regression equations for determination of height of a person. ${ }^{19-24}$

All the above studies prove that several anthropological parameters have a direct bearing on identification and stature estimation. This fundamental principle has formed the basis of determination of height of an individual using middle finger length. A variety of studies have been conducted over the years using length of digits in an attempt to predict stature of an individual. However, in a country of varied ethnicity and regional diversity, there is no one study nor any one result applicable to all.

We wanted to evaluate the relationship between middle finger length and stature of an individual in the state of Uttar Pradesh.

\section{METHODS}

This is a descriptive study. Institutional ethical clearance was obtained prior to commencement of the study. Simple random sampling method was used in a batch of 110 MBBS students. Ninety subjects (Keeping a margin of error 4, confidence level of $95 \%$, using software) of which forty-five were male and forty-five female, in the age group of 18-25 years were studied in the Department of Forensic Medicine \& Toxicology, Heritage Institute of Medical Sciences, Varanasi (Uttar Pradesh). A written informed consent was obtained from the subjects.

Subjects who had metabolic, nutritional, developmental, congenital or traumatic defects of middle finger were excluded. The subjects who refused to give consent were also not included in the study. Height was calculated using an anthropometer. The subject was made to stand erect against an anthropometer, barefoot, with head, buttocks and heel touching the vertical rod. The head was positioned in Frankfurt plane and readings were taken after moving the head plate to rest flat on the top of head.

A digital vernier calliper was used to measure the middle finger length. The subject was asked to rest his/her hand flat on the table in supine position with fingers extended and spread apart. The blades of the vernier calliper was placed such that it measured the distance between the proximal most flexion crease of the middle finger and the tip of the middle finger. This was performed on middle finger of both hands. In order to eliminate any inter observer error and intra observer error, all measurements were taken thrice by a single examiner alone.

\section{Statistical Analysis}

The data obtained was analysed and mean values, standard deviation and various centiles were calculated separately for males and females. The difference between males and females was studied using independent student's t-test. Gender specific centile charts were constructed the data was collected and correlated statistically by SPSS software package version 26.0 and a linear regression formula was obtained.

\section{RESULTS}

Table 1 shows maximum, minimum and mean values, along with the standard deviation for each parameter. The mean middle finger length of $7.616(\mathrm{SD}=0.52904) \mathrm{cm}$ on right side as compared to $7.589(\mathrm{SD}=0.5099) \mathrm{cm}$ on left side indicate that the descriptive parameters are more on right side as compared to left side. Table 2 elicits the correlation coefficient and p-value of middle finger of both hands in an individual. The difference between male and female values 
was analysed using independent student's t-test. It was observed that the right middle finger length $(\mathrm{r}=0.760)$ shows greater correlation with stature than left middle finger length $(r=0.701)$.The statistical analysis revealed that middle finger length of both hands showed significant correlation with height of the subject. In Table 3 regression equation is obtained by calculating y which is the predicted height, from Constant (c), Regression coefficient (m) and middle finger value $(\mathrm{x})$. The formula $\mathrm{y}=\mathrm{c}+\mathrm{mx}$ was applied.

Table 4 reinforces the correlation of stature with middle finger length. It was further demonstrated that whilst both the parameters show a highly significant statistical correlation, the right middle finger length $(r=0.760)$ is the better parameter for prediction of height than left middle finger $(r=0.701)$.

\begin{tabular}{|c|c|c|c|c|}
\hline Parameter & Minimum & Maximum & Mean & SD \\
\hline Height & 143.4 & 194.9 & 161.599 & 9.8509 \\
\hline Right Middle Finger Length & 6.31 & 8.91 & 7.616 & 0.52904 \\
\hline Left Middle Finger Length & 6.52 & 8.99 & 7.589 & 0.50999 \\
\hline Table 1. Minimum, Maximum, Mean Values and Standard Deviation \\
of Both Hands Middle Finger (MF) and Height of a Subject \\
\hline
\end{tabular}

\begin{tabular}{|c|c|c|}
\hline Parameter & Correlation Coeff. (r) & p Value \\
\hline Rt MF & 0.760 & $<0.001$ \\
\hline Lt MF & 0.701 & $<0.001$ \\
\hline \multicolumn{2}{|c|}{ Table 2. Correlation Coefficient and p Value Between Height and } \\
Middle Finger Length of Both Hands of an Individual \\
\hline
\end{tabular}

\begin{tabular}{|c|c|c|}
\hline Parameter & R2 & Regression Formula $\mathbf{y}=\mathbf{m x}+\mathbf{c}$ \\
\hline Rt MF & 0.5789 & $14.167 \mathrm{x}+53.707$ \\
\hline Lt MF & 0.4917 & $13.545 \mathrm{x}+58.807$ \\
\hline \multicolumn{2}{|c|}{ Table 3. Regression Formula is Calculated for each Parameter } \\
\hline
\end{tabular}

\begin{tabular}{|c|c|c|}
\hline Parameter & Pearson Correlation & Sig. (2- tailed) \\
\hline Rt MF & 0.760 & $0.000^{*}$ \\
\hline Lt MF & 0.701 & $0.000^{*}$ \\
\hline \multicolumn{2}{|c|}{ Table 4. Correlation Between the Stature of an Individual } \\
and the Middle Finger Length \\
\hline * Correlation is significant at the 0.05 level (2-tailed) \\
\hline
\end{tabular}

\begin{tabular}{|c|c|c|c|}
\hline Authors & Region & $\begin{array}{l}\text { Middle } \\
\text { Finger }\end{array}$ & Regression Equation \\
\hline Present study & Uttar Pradesh & $\begin{array}{c}\text { Right } \\
\text { Left }\end{array}$ & $\begin{array}{l}S=14.167 \times \text { RMFL }+53.707 \\
S=13.545 \times \text { LMFL }+58.807\end{array}$ \\
\hline Rastogi P et al & $\left|\begin{array}{l}\text { North Indians } \\
\text { South Indians }\end{array}\right|$ & Right & $\begin{array}{l}\mathrm{S}=117.20+6.82 \times \text { RMFL }(\mathrm{m}) \\
\mathrm{S}=99.54+8.044 \times \text { RMFL }(\mathrm{f}) \\
\mathrm{S}=95.90+9.517 \times \text { RMFL }(\mathrm{m}) \\
\mathrm{S}=110.93+6.52 \times \text { RMFL }(\mathrm{f})\end{array}$ \\
\hline Katwal B et al & Kathmandu & Right & $\begin{array}{c}S=131.29+0.422 \times \text { RMFL }(\mathrm{m}) \\
\mathrm{S}=115.65+0.442 \times \text { RMFL }(\mathrm{f})\end{array}$ \\
\hline Rahule et al. & $\begin{array}{l}\text { Andhra } \\
\text { Pradesh }\end{array}$ & Right & $\begin{array}{c}\mathrm{S}=120.74+0.457 \times \mathrm{XMFL}(\mathrm{m}) \\
\mathrm{S}=93.56+0.636 \times \text { RMFL }(\mathrm{f})\end{array}$ \\
\hline Shivakumar $\mathrm{AH}$ et al & Karnataka & $\begin{array}{l}\text { Right } \\
\text { Both }\end{array}$ & $\begin{array}{c}\mathrm{S}=152.02+1.47 \times \mathrm{RMFL}(\mathrm{m}) \\
\mathrm{S}=90.54+6.9 \times \text { MFL }(\mathrm{f})\end{array}$ \\
\hline Verghese AJ et al & Karnataka & $\begin{array}{l}\text { Right } \\
\text { Left }\end{array}$ & $\begin{array}{l}S=120.20+4.95 \times \text { RMFL }(\mathrm{m}) \\
S=117.55+4.26 \times \text { RMFL }(\mathrm{f}) \\
S=117.11+5.27 \times \text { LMFL }(\mathrm{m}) \\
S=115.77+4.43 \times \text { LMFL }(\mathrm{f})\end{array}$ \\
\hline \multicolumn{4}{|c|}{$\begin{array}{c}\text { Table 5. Comparative Analysis of Different Studies with their } \\
\text { Regression Formulae in Male ( } m \text { ) and Female (f) of Right (RMF) } \\
\text { or Left (LMF) Middle Fingers }\end{array}$} \\
\hline
\end{tabular}

\section{DISCUSSION}

Forensic anthropology deals with examination of human remains with the purpose to assist administration of justice, while forensic osteology deals specifically with human bones. Multitude of questions can be answered from bones and human body parts. Whether they are live tissue or not, human or some other species, belonging to one or many individuals, sex, race, age, stature, cause of death and time since death. There are several published literature and books on determination of stature from different type of bones, be it humerus, radius, ulna, femur, tibia, fibula or skull and from mutilated remains like arm, palm, or fingers. The present study using middle finger length, also helps to narrow down the identification of an individual if faced with a sea of comingled remains as in cases of mass disasters. As determined by the current study, there exists a significant correlation between stature of an individual and middle finger length. This is in agreement with various studies conducted by Rastogi $\mathrm{P}$ et $\mathrm{al}^{25}$ Katwal B et al, ${ }^{26}$ Mudasir Ahmad Khan et al $^{27}$ Rahule et al. ${ }^{28}$ Shivakumar AH et al, ${ }^{29}$ Verghese $\mathrm{AJ}$ et $\mathrm{al}^{30}$ and Tyagi AK et al. ${ }^{31}$

Rastogi et al concluded that middle finger length can be used as an important tool in determination of height of an individual which was resonated in the study by Katwal B et al. Rastogi et al gave a regression equation of $\mathrm{S}=117.20+6.82 \mathrm{X}$ Right Middle finger length for males in North India and $S=$ 99.54+8.044 X Right Middle finger length for females of the same region. They conducted the same study on South Indian population and derived the equation as $S=95.90+9.517 \mathrm{X}$ Middle finger length for males and $S=110.93+6.52 \mathrm{X}$ Middle finger length for females. Mudasir Ahmad Khan et al derived linear regression formula revealing that middle finger length can be a successful predictor of stature. Rahul at al suggested that females showed a more significant correlation between stature and middle finger length and formulated the regression equation as $S=120.74+0.457$ X Right Middle finger length for males and $S=93.56+0.636 \times$ Right Middle finger length for females living in Andhra Pradesh. The right middle finger length showed a higher statistical correlation with height in the study conducted by Shivakumar AH et al in Karnataka, S=152.02+1.47 X Right Middle finger length (Males). Verghese AJ et al conducted the same study in the same region with similar results deriving regression equation as $S=120.20+4.95 \mathrm{X}$ Right Middle finger length in males and $\mathrm{S}=117.55+4.26 \mathrm{X}$ Right Middle finger length in females and for the left hand, $S=117.11+5.27 \mathrm{X}$ Left Middle finger length (Males), $S=115.77+4.43 \quad \mathrm{X}$ Left Middle finger length (Females).

\section{CONCLUSIONS}

Intact middle finger of either hand of an individual can be used as successful predictor of height of the same individual, with the right middle finger length being a better determinant of stature than left middle finger length in the region of Uttar Pradesh.

\section{REFERENCES}

[1] Hasegawa I, Uenishi K, Fukunaga T, et al. Stature estimation formulae from radiographically determined limb bone length in a modern Japanese population. Leg Med (Tokyo) 2009;11(6):260-6.

[2] Didia BC, Nduka EC, Adele O. Stature estimation formulae for Nigerians. J Forensic Sci 2009;54(1):20-1. 
[3] Simmons T, Jantz RL, Bass WM. Stature estimation from fragmentary femora: a revision of the Steele method. J Forensic Sci 1990;35(3):628-36.

[4] Krishan K. Anthropometry in forensic medicine and forensic science-'Forensic Anthropometry'. The Internet Journal of Forensic Science 2007;2(1). DOI: 10.5580/1dce [cited 2014 Nov 05].

[5] Sheta A, Hassan M, Elserafy M. Stature estimation from radiological determination of humerus and femur lengths among a sample of Egyptian adults. Bull Alex Fac Med 2009;45:479-86.

[6] Krishan K. Estimation of stature from cephalo-facial anthropometry in North Indian population. Forensic Sci Int 2008;181(1-3):52.e1-6.

[7] Kumar J, Chandra L. Estimation of stature using different facial measurements among the Kabui Naga of Imphal valley, Manipur. Anthropologist 2006;8(1):1-3.

[8] Jadhav HR, Shah GV. Determination of personal height from the length of head in Gujarat region. J Anat Soc India 2004;53(1):20-1.

[9] Holland TD. Estimation of adult stature from fragmentary tibias. J Forensic Sci 1992;37(5):1223-9.

[10] Jason DR, Taylor K. Estimation of stature from the length of the cervical, thoracic and lumbar segments of the spine in American Whites and Blacks. J Forensic Sci 1995;40(1):59-62.

[11] Mohanty NK. Prediction of height from percutaneous tibial length amongst Oriya population. Forensic Sci Int 1998;98(3):137-41.

[12] Ozaslan A, Iscan MY, Ozaslan I, et al. Estimation of stature from body parts. Forensic Sci Int 2003;132(1):40-5.

[13] Hauser R, Smolinski J, Gos T. The estimation of stature on the basis of measurements of the femur. Forensic Sci Int 2005;147(2-3):185-90.

[14] Bhavna, Nath S. Estimation of stature on the basis of measurements of the lower limb. Anthropologist Spec 2007;3:219-22.

[15] Duyar I, Pelin C, Zagyapan R. A new method of stature estimation for forensic anthropological application. Anthropological Science 2006;114(1):23-7.

[16] Bidmos MA, Asala S. Calcaneal measurement in estimation of stature of South African Blacks. Am J Phys Anthropol 2005;126(3):335-42.

[17] Krishan K, Sharma A. Estimation of stature from dimensions of hands and feet in a North Indian population. J Forensic Leg Med 2007;14(6):327-32.

[18] Udhaya K, SaralaDevi KV, Sridhar J. Regression equation for estimation of length of humerus from its segments: a South Indian population study. Journal of Clinical Diagnostic Research 2011;5(4):783-6.
[19] Jasuja OP, Singh J, Jain M. Estimation of stature from foot and shoe measurements by multiplication factors: a revised attempt. Forensic Sci Int 1991;50(2):203-15.

[20] Jasuja OP, Manjula. Estimation of stature from footstep length. Forensic Sci Int 1993;61(1):1-5.

[21] Ozdena H, Balcib Y, Demirustu C, et al. Stature and sex estimate using foot and shoe dimensions. Forensic Sci Int 2005;147(2-3):181-4.

[22] Patel SM, Shah GV, Patel SV. Estimation of height from measurements of foot length in Gujarat region. J Anat Soc India 2007;56(1):25-7.

[23] Zeybek G, Ergur I, Demiroglu Z. Stature and gender estimation using foot measurements. Forensic Sci Int 2008;181(1-3):54.e1-5.

[24] Sen J, Ghosh S. Estimation of stature from foot length and foot breadth among the Rajbanshi: an indigenous population of North Bengal. Forensic Sci Int 2008;181(13):55.e1-6.

[25] Rastogi P, Kanchan T, Menezes RG, et al. Middle finger length - a predictor of stature in the Indian population. Med Sci Law 2009;49(2):123-6.

[26] Katwal B, Panta PP, Pandit R, et al. Estimation of stature from length of middle finger among Nepalese medical student of Nepal Medical College and Teaching Hospital. MedPulse International Journal of Forensic Medicine 2017;3(1):01-04. https://www.medpulse.in/Forensic\%20Medicine/

[27] Khan MA, Khan JA, Khan MA, et al. Middle Finger Length - a predictor of stature in J\&K state. Global Journal for Research Analysis 2017;6(6):151-4.

[28] Rahule AS, Rao SB, Mohd Saleem, et al. A study of correlation between middle finger length and height in a tribal district population of India. J Cont Med A Dent 2013;1(1):8-12.

[29] Shivkumar AH, Raju GM, Vijaynath V. Prediction of stature by right middle finger length of males among south Indian population. Journal of Pharmaceutical and Scientific Innovation 2013;2(1):31-3.

[30] Verghese AJ, Balaraj BM, PramodKumar GN. A study of estimation of stature from length of fingers in Mysore. Indian Journal of Forensic Medicine \& Toxicology 2010;4(2):12-13.

[31] Tyagi AK, Kohli A, Verma SK, et al. Correlation between stature and fingers length. International Journal of Medical Toxicology and Legal Medicine 1999;1(2):20-2. 